\title{
Chapter

\section{Ecology and diversity of plant aphids in Garhwal region of Uttarakhand, India}

\author{
Sunil Kumar* and Deepa Saini \\ Department of Zoology, D.A.V.(P.G.) College, Dehradun (Uttarakhand), India
}

Arthropod insect aphids, also known as plant lice, are small soft bodied insects that suck the sap of the plant. Which belong to the subfamily Aphidinae. There are about 400 species of aphids under 60 genera worldwide. Out of which 125 species of aphids are found under 25 genera in India and in Uttarakhand (plain region to very high altitude) under 4 genera of aphids 65 species of aphids are found, of which the genus Aphidius represents the largest number of species. Aphids are abundant in temperate climates and attack a wide variety of plants causing great damage to agricultural crops, horticultural fruits and vegetables. Its outbreak is influenced by temperature, humidity and other environmental factors. Aphids are small, soft bodied, wingless, viviparous and parasitoid insects which have a pair of tube like projections cornicles or wax secreting tube on the abdomen, that may stunt plant growth, produce plant galls, transmit plant virus diseases, and cause the deformation of leaves, buds, and flowers. They affect the crops like mustard, cabbage, pea, potato, bean, lemon, cotton etc. and flowers like rose, lily, marigold etc. There is a lack of information about aphid diversity, ecology and inventory in the mountainous region. Thus in this study an attempt has been made to review and survey the diversity of aphids in the Uttarakhand Garhwal region.

\section{Keywords}

Altitude, Aphidiinae, Genera, Temperate climate

$\square$ Sunil Kumar, Email: sunilkumarddn@yahoo.co.in ( ${ }^{*}$ Corresponding author) 


\section{Introduction}

Arthropod pests like aphids (Hemiptera) belong to family Aphididae also known as plant lice, greenfly, or ant cow group of sap-sucking, soft-bodied insects can damage plants and their leaves which are important for photosynthesis. Aphids are small, soft bodied, wingless, viviparous and parasitoid insects which have a pair of tube like projections cornicles or wax secreting tube on the abdomen, that may stunt plant growth, produce plant galls, transmit plant virus diseases, and cause the deformation of leaves, buds, and flowers. They affect the crops like mustard, cabbage, pea, potato, bean, lemon, cotton etc. and flowers like rose, lily, marigold etc. Aphids belong to Phylum Arthropoda, Class - Insecta, Order - Hemiptera, Suborder - Sternorrhyncha, Superfamily - Aphidoidea, Family - Aphididae, sub family - Aphidiinae. Approximately 400 species placed under 60 genera of subfamily Aphidiinae have been described worldwide (Belshaw and Quicke, 2001). This subfamily was traditionally represented by four tribes, viz., Ephedrini, Praini, Aphidiini and Trioxini but molecular phylogenetic analysis have proved to be three viz., Ephedrini, Praini and Aphidiini (Smith et al., 1999) or five viz., Ephedrini, Praini, Monoctonini, Trioxini and Aphidiini tribes (Sanchis et al., 2005).

In India, this subfamily is represented by 125 species belonging to 22 genera under four tribes viz., tribe Ephedrini with 4 genera viz. Toxares, Ephedrus, Indoephedrus and Neoephedrus; tribe Praini with 2 genera viz., Areopraon and Praon; tribe Aphidiini with 12 genera viz., Adialytus, Aphidius, Archaphidus, Diaeretiella, Diaeretus, Indaphidius, Kashmiria, Lipolexis, Lysiphlebia, Lysiphlebus, Monoctonus and Pauesia and tribe Trioxini with 4 genera viz., Betuloxys, Binodoxys, Cristicaudus and Trioxys occurring from the plains to very high altitudes of Himachal Pradesh, Jammu and Kashmir, West Bengal and Uttarakhand. An analysis of the literature reveals that as many as 95 species have been reported from North West India from the states of Delhi, Himachal Pradesh, Jammu and Kashmir, Punjab, Uttar Pradesh and West Bengal; 41 species from the states of north east India viz., Assam, Manipur, Meghalaya, Nagaland, Sikkim and Tripura and 13 species from south India viz., Karnataka and Tamil Nadu. An inventory of the biodiversity of aphidiini parasitoids associated with aphids in India showed 123 species under 23 genera to be intensively and extensively exercising natural control. Aphids are cosmopolitan in distribution and are found abundant in temperate climate and attack a wide variety of plants (De Barro and Carver, 1997). The inventory has been reinforced with all associated details, mainly zoogeographical distribution, parasitism potential attributes and other such relative details from primary sources so as to make it serve as an important start up tool for planning any IPM strategy, involving bio control of aphids (Dey and Akhter, 2007). Aphids are often controlled by natural enemies such as ladybird beetles, aphid lions, and lacewings. However, when economically or aesthetically damaging numbers are present, they can be controlled by insecticidal soaps, horticultural oils, and other traditional insecticides. Aphids cause great loss to agriculture crops, horticulture fruits and vegetables. Its outbreak is affected by temperature, humidity and other environmental factors (Bannerman and Roitberg, 2014). There is lack of information on the aphid diversity, ecology and inventory in mountain region. Thus an attempt has been made to review and survey the diversity of aphids in Uttarakhand Garhwal region. 


\section{Life cycle of aphids}

The life cycle of the aphid is complicated. Wingless females, called stem mothers, reproduce without fertilization (parthenogenetically) throughout the summer. These stem mothers are unique in that they produce living young ones (viviparity) as opposed to eggs as occurs in most other insects. Eventually the plant containing the stem mother and her offspring becomes overcrowded. When this occurs, some offspring develop into adults with two pairs of large membranous wings. These winged adults fly to new plants. In late summer both males and females are produced. After they mate, the female lays eggs that survive the winter. In warm climates there may be no need for an overwintering egg stage, and continuous generations occur. The white woolly-ball appearance of many aphids is the result of wax-gland secretion. Aphids reproduce by thelytokous parthenogenesis in spring and summer under conditions of long day length and high temperatures. In aphids with a holocyclic life cycle, males and oviparous (sexual) females appear in late autumn and produce fertilized eggs for overwintering. Aphids employ the $\mathrm{XO}$ sex-determination system. Therefore, viviparous and oviparous females possess two $X$ chromosomes, while males possess only one $X$ chromosome. Males are produced parthenogenetically with the random loss of one $X$ chromosome during the maturation division. Although oviparous females and males produce haploid oocytes and sperm, respectively, by reductive meiosis, only sperm possessing an $\mathrm{X}$ chromosome are viable (sperm lacking an $\mathrm{X}$ chromosome are degenerate). Therefore, the next generation, which will hatch as fundatrices in the spring, is entirely female (XX) i.e. Viviparous, parthenogenetic female; Oviparous, sexual female (Chan and Forbes, 2019) (Figure 1).

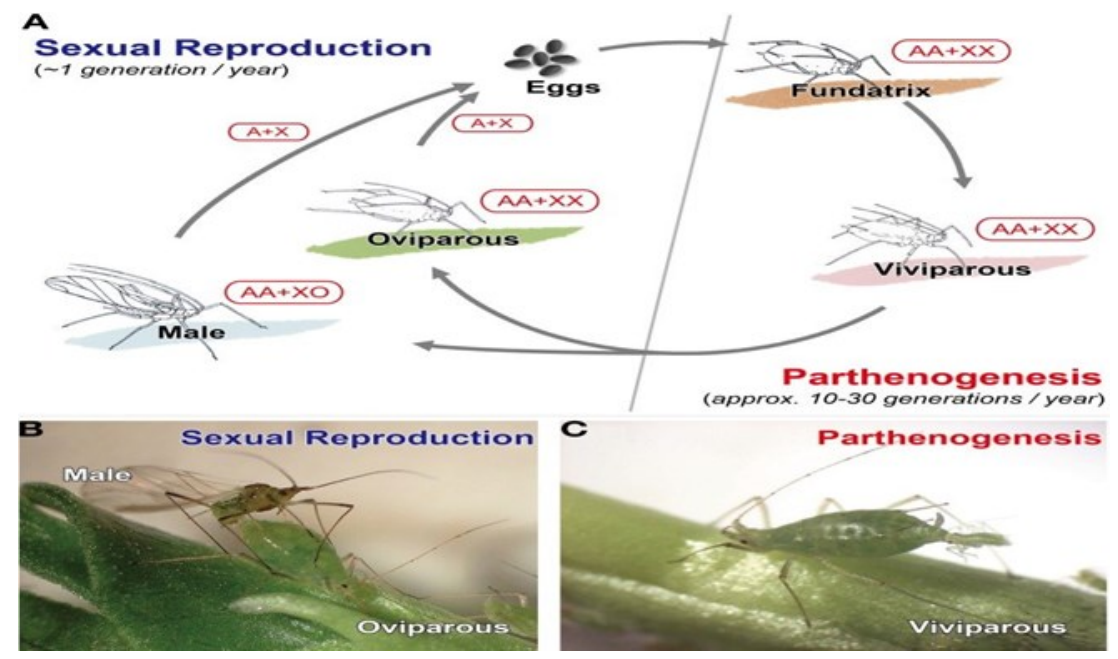

Figure 1. Typical annual life-cycle of aphids, (A) Schematic diagram of a typical holocyclic life cycle of aphids, (B) Sexual individuals (male and oviparous female) of Acyrthosiphon pisum, (C) viviparous female of A. pisum. 


\section{Aphids as vector for the viruses}

Aphids are most common group of vectors for the several viral diseases as, Alfalfa mosaic virus, Bean common mosaic virus, Calotropis ringspot mosaic virus, Cauliflower mosaic virus, Citrus tristeza virus, Citrus woody gall virus, Cowpea (aphid-borne) mosaic virus, Cucumber mosaic virus, Garlic mosaic virus, Green gram mosaic virus, Infectious chlorosis of banana, Leaf crinkle of sunflower, Lily symptomless virus, Muskmelon yellow stunt virus, Onion yellow dwarf virus, Papaya ringspot virus, Passion fruit Sri Lankan mottle virus, Pepper veinal mottle virus, Potato leaf roll virus, Potato virus, Solanum trovum mosaic virus, Sri Lankan passion fruit mottle virus, Sugarcane mosaic virus, Sweet potato feathery mottle virus, Turnip mosaic virus, Watermelon mosaic 1 virus, Watermelon mosaic 2 virus, Yam mosaic virus, Sunflower yellow blotch virus, Yellow vein mosaic virus, Zucchini yellow mosaic virus (Ebert and Cartwright, 1997, James et al., 2004).

\section{Aphids Honeydew}

Aphids feed on the phloem sap of plants, and are the most common honeydew (sweet excretory product) producing insects. While aphid honeydew is primarily considered to comprise sugars and amino acids, its protein diversity has yet to be documented. On the investigation of the honeydew proteome from the aphid using a two-Dimensional Differential in-Gel Electrophoresis demonstrating that aphid honeydew also represents a diverse source of proteins. The protein diversity of aphid honeydew originates from several organisms (the host aphid and its microbiota, including endosymbiotic bacteria and gut flora). Honeydew is also the keystone on which ant-aphid mutualism is built (Sabri et al., 2013). Ants may guard and care for aphids in return for the honeydew they produce. Ants protect aphids from weather and natural enemies and transfer them from wilted to healthy plants. In this way the ants ensure their source of honeydew, which they use as food. Ants obtain honeydew by stroking, or "milking," the aphids (Shik, 2014).

\section{Alate production}

There are two forces proposed as triggers for alate production in A. gossypii: nutritional factors and crowding. Starved nymphs from apterous parents resulted in $13 \%$ alates versus $0.4 \%$ from unstarred nymphs. However, starvation of nymphs from alate parents resulted in no increase in alate formation. A similar result was also reported for starved parents, where starved apterous parents produced more alate progeny than well-fed apterous parents (23\% versus $2 \%$, respectively) and there was no increase in alate formation by starved alate parents. Nutritional factors from other sources can affect $A$. gossypii development. In considering the possible role of aphid-borne plant viruses, the survival of the virus is dependent on having an efficient aphid vector, and the most efficient vector is alate. Therefore one might expect that a virus would promote conditions favouring alate production in the aphid. Alate 
production in the melon aphid-courgette-Zucchini yellow mosaic virus system appeared to increase on infected plants. Blua and Perring (1992) decided that nutritional factors are the cause for increased alate production. To further support the argument that the cause might be nutritional, it has been shown that aphid infestations on Solanum integrifolium changes peroxidase, esterase and protein content of the plant in proportion to the level of infestation (Owusu et al., 1994). This shows a change in plant nutrient content associated with aphid density which might form a chemical link between nutrition and alate production. Additional factors which influence alate production include crowding and type of parent (apterous or alate) and the possible effects of light and temperature (Guldemond et al., 1994).

\section{Host plant and behaviour}

Flight is the beginning of the dispersal phase in the aphid life cycle. It begins with the pre-flight period (from moult to flight) which lasted from 1 to 31 hours with most activity 10-24 hours after moult from colonies reared on Veronica persica. The general pre-flight period increased from 10 to over 70 hours with decreasing temperatures from 28 to $12^{\circ} \mathrm{C}$. Adults flew from about sunrise to early afternoon, but a few individuals continued to fly after dark. With first light at $06.00 \mathrm{~h}$, and last light at $19.30 \mathrm{~h}$, no flight was detected from $23.00 \mathrm{~h}$ to $07.00 \mathrm{~h}$. In laboratory colonies, the flight period lasted from 1 to 4 days (Nozato, 1990). Orientation to host plants was significant at 6 hours after wing development, but was highly significant after 24 hours. Alates were able to distinguish between different plants; Cucurbita pepo and Thunbergia laurifolia were attractive, and were common hosts for A. gossypii in Cuba. The occasional host Hibiscus rosa-sinensis was neither attractive nor repellent, and the non-host plant Lantana camara was repellent. L. camara found in locations other than Cuba has been recorded as a summer host of A. gossypii. This apparent contradiction is due to differences in aphid populations and relationship with host plant found in differing geographical areas (Zepeda et al., 2017).

\section{Study area}

Garhwal region of Uttarakhand is located in the North Hill part of India, between latitude from $30^{\circ} 15^{\prime}$ $\mathrm{N}$ to $31^{\circ}-28^{\prime}$ North and Longitude $79^{\circ} 15^{\prime}$ to $81^{\circ}-02^{\prime}$ East. Garhwal is the western region and administrative division of Uttarakhand (Figure 2). Lying in the Himalayas, it is bounded on the north by Tibet, on the east by Kumaon region, on the south by Uttar Pradesh state, and on the northwest by Himachal Pradesh state. It is characterized by two types of climate, sharply differentiated in the plains and the mountainous regions with lush green forest and landscape quite rich in natural resource. GPS Garmin-US was used for latitude, longitude and altitude during field survey. Aphids were collected from different sites and altitude and identified by the method (Blackman and Eastop, 2000; Martin, 2008). A survey conducted for Aphid diversity at different crops and altitudes in the Garhwal region of Uttarakhand. Species identified from different crops were as follows (Figure 3): 


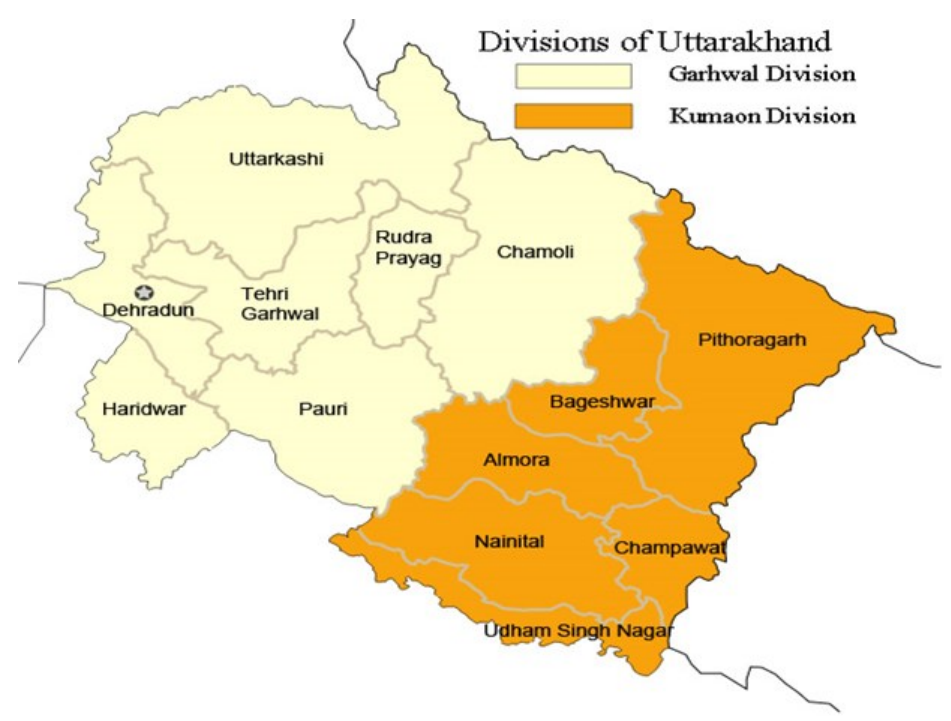

Figure 2. Map of Aphids diversity and ecology in Garhwal region of Uttarakhand.

\section{Cotton aphid (Aphis gossypii)}

The melon, or cotton, aphid is green to black. In warm climates live young are produced all year, while in cooler areas there is an egg stage. Among the dozens of possible hosts are melon, cotton, and cucumber. It is usually controlled by naturally occurring parasites and predators. Aphis gossypii is small, adaptable, easily spread, with a rapid reproductive rate, and the ability to cause serious plant injury in isolated communities. Aphis gossypii Glover is highly polyphagous and is now considered to consist of distinct phenotypes and genotypes, both holocyclic and anholocyclic, that vary with respect to their ability to reproduce and food preferences on different host plants. Plants belonging to following families are highly infested: Asteraceae, Cucurbitaceae, Fabaceae, Lamiaceae, Malvaceae, Polygonaceae, Rosaceae and Solanaceae (Singh et al., 2014).

Taxonomically, A. gossypii is difficult to separate from Aphis frangulae. (Strogani, 1984) regarded A. gossypii as a sub-species of A. frangulae. Cotton-melon aphid Aphis gossypii is a fine life system to study the evolution of feeding habit because of the short life history, various reproductive modes, and wide host plant range (Liu et al., 2005). Following characteristics were used to identify A. gossyppiii. The cornicles or siphunculi are uniformly sclerotized from tip to base, and darkly pigmented. They are longer than the cauda and gradually taper towards the apex with a small dilation there. The dorsal abdominal segments are uniformly sclerotized and unpigmented. A. gossypii reared near the colour transition temperature often have a blotchy appearance with some parts greenish and other parts more yellow. The cauda usually have 4-7 hairs and are paler than the cornicles. Stidulatory apparatus is absent. The antennal tubercles are weakly developed. The terminal process is more than twice the length of the last antennal segment, but less than 3.5 times as long (Singh and Srivastava, 1989). 


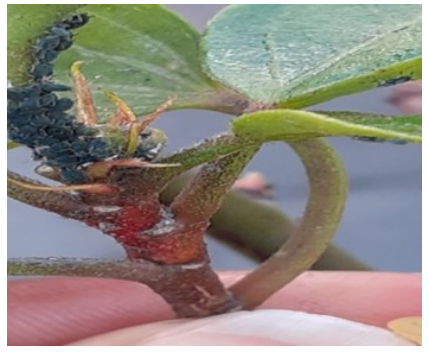

Cotton aphid (Aphis gossypii)
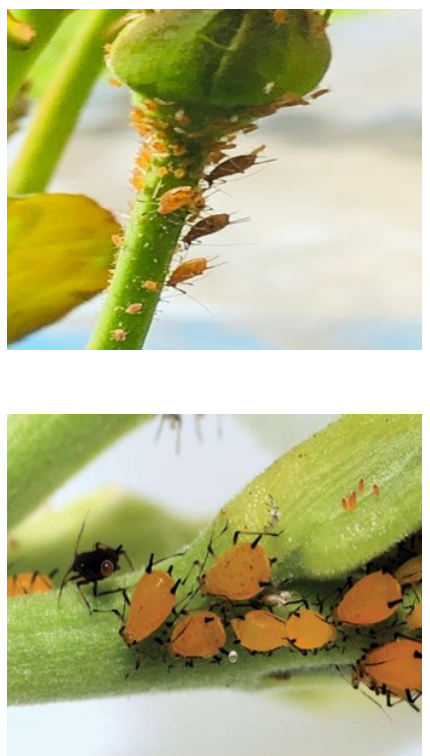

Pea aphid (Acyrthosiphon pisum)

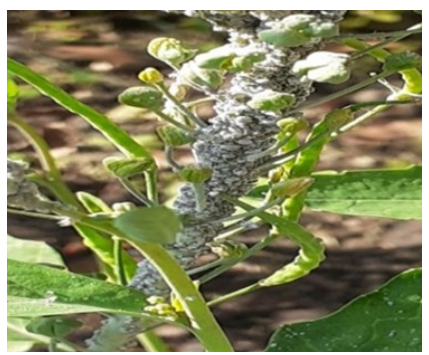

Aphis craccivora (cowpea aphid/ Ground nut aphid)
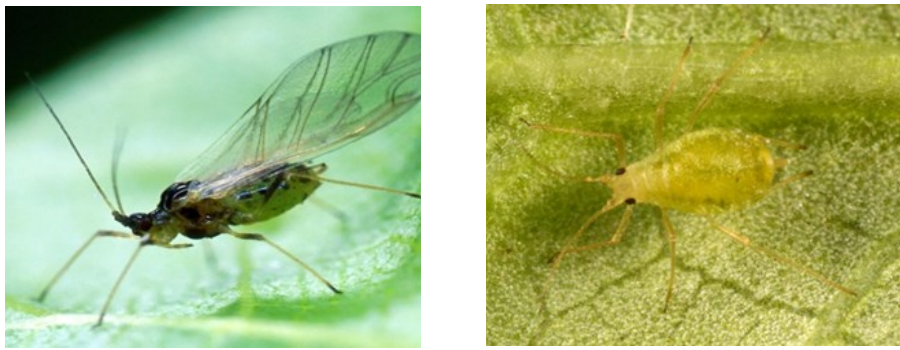

Myzus persicae (Sulzer) nymp
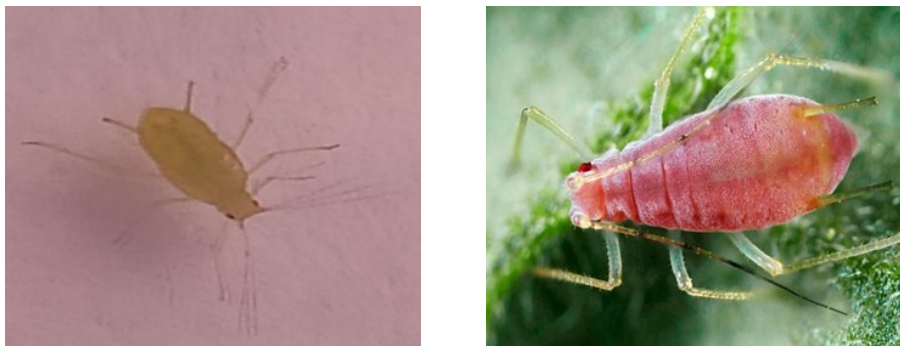

Rose aphid (Macrosiphum rosae)

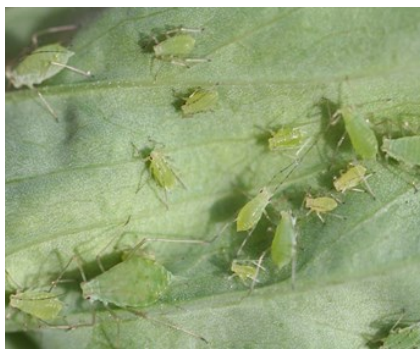

Potato aphid (Macrosiphum euphorbiae)
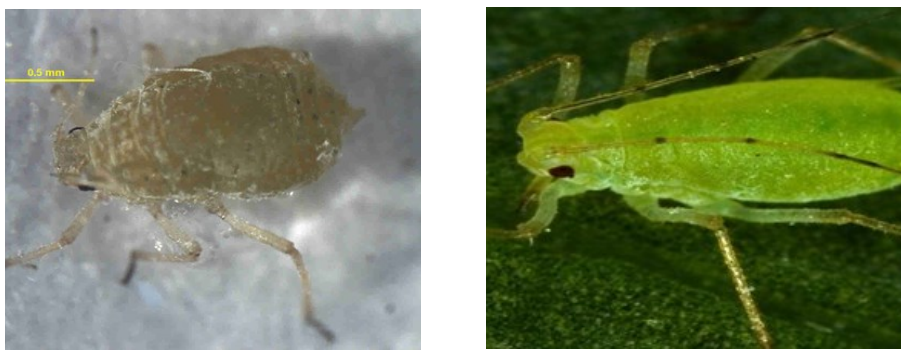

Cabbage aphid (Brevicoryne brassicae)

Figure 3. Selected aphids species of Uttarakhand. 


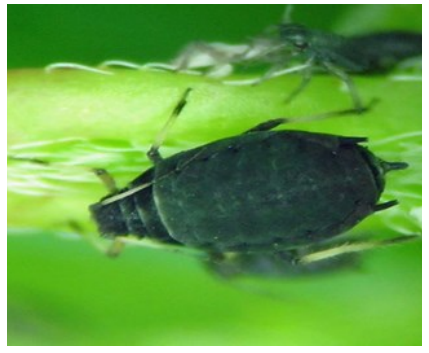

Black bean aphid (Aphis Fabae)
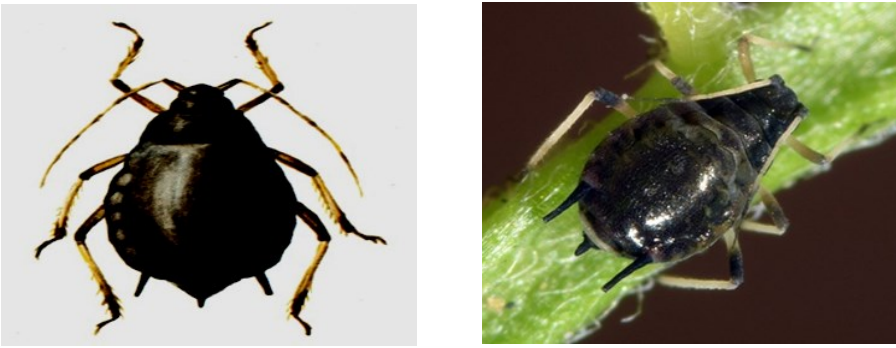

Green citrus aphid (Aphis spiraecola)

Figure 3. Continued...

A. gossypii is a small aphid. Adults range from just under $1-1.5 \mathrm{~mm}$ in body length. The minimum diameter is just over $0.34 \mathrm{~mm}$. This is indicated by the fact that a screen with a mesh diameter of under $0.34 \mathrm{~mm}$ is able to exclude A. gossypii (Bethke and Paine, 1991). Other characteristics combined can provide greater separation between instars especially under constant temperatures. A. gossypii can range in colour from yellow to very dark (almost black) green. The smaller yellow form occurs during warmer summer conditions. The green form is larger and occurs during cooler spring and autumn temperatures, and uncrowded conditions. Colour morphs are able to produce progeny of another colour morph. Host plant can also influence aphid colour (Ebert and Cartwright, 1997). The initial symptom of A. gossypii attack is a yellowing of the leaves. As populations continue to rise, aphids move to younger leaves, stems and flowers (sepals mostly). Plants become covered with a black sooty mould which grows on the honeydew excreted by the aphid. At very high densities, A. gossypii is able to kill its host. A. gossypii exhibits an anholocyclic life cycle, while in cooler areas it exhibits either a heteroecious or autoecious holocyclic life cycle (Zhang and Zhong, 1990). The heteroecious cycle involves a migration from a winter host to a summer host in the spring and a return to a winter host in the autumn for laying eggs. Significant differences were found in birth rates of A. gossypii reared on cotton, watermelons and groundnuts (Ekukole, 1990). The optimal temperature for reproduction is $20-25^{\circ} \mathrm{C}$ when the aphid can produce an average of 2.8 nymphs per day (Akey and Butler, 1989). The most important impact $A$. gossypii has on world agriculture is through its ability to transmit plant viruses. $A$. gossypii on okra infected with Yellow-vein mosaic virus did not reproduce as fast as those on healthy okra.

\section{Green peach aphid (Myzus persicae)}

The green peach aphid (Myzus persicae), also called the spinach aphid, is pale yellow-green with three dark lines on the back. The life cycle involves two hosts. The female reproduces parthenogenetically during summer and produces sexual males and females in autumn. It is a serious pest, transmitting many plant mosaic diseases. Adult wingless parthenogenetic females are oval-bodied, $1.2-2.1 \mathrm{~mm}$ in body length, of very variable colour; whitish green, pale yellow green, grey green, mid-green, dark green, pink or red. Apart from genetically determined colour variation, any one genotype will be more 
deeply pigmented green or magenta in cold conditions. Immature stages are quite shiny, but adults are less so. Winged morphs have a black central dorsal patch on the abdomen. Immatures of the winged females are often pink or red, especially in autumn populations, and immature males are yellowish (Blackman and Eastop, 1984). Myzus persicae is probably of Asian origin, like its primary host plant (Prunus persica) but now occurs everywhere in the world except where there are extremes of temperature or humidity.

Myzus perssica inspect for curled leaves, in which colonies develop in early spring. Monitoring is important in field crops, but M. persicae transmits viruses of crops such as sugar beet and potato at low densities, and is therefore difficult to detect on the crop before the damage is done. Suction and yellow traps are the most efficient way to detect first migration of winged aphids into the crop. Networks of suction traps have been developed to monitor migrating aphids, for example, the Rothamsted Insect Survey in the UK and AGRAPHID in France (Hulle et al., 2000). It is not clear whether the sexual part of the life-cycle is completed on species other than P. persica and P. nigra. M. persicae is highly polyphagous on summer hosts, which are in over 40 different families, including Brassicaceae, Solanaceae, Poaceae, Leguminosae, Cyperaceae, Convolvulaceae, Chenopodiaceae, Compositae, Cucurbitaceae and Umbelliferae. Summer hosts include many economically important plants in flowering stage, Post-harvest, Seedling stage, Vegetative growing stage. Effect of infestation depends greatly on host plant and transmitted viruses. Spring populations on peach cause severe leaf curl and shoot distortion. In potato, PLRV symptoms are leaf rolling and tuber stem necrosis. Ghosh and Verma (1990) reported apterous oviparous females of M. persicae first time from India, collected on Prunus persica.

A series of generations of wingless (apterous) and alate virginoparae are produced viviparously by thelytokous (all-female) parthenogenesis. Autumn migrants (gynoparae), migrate back to peach. Gynoparae will attempt to colonize a range of trees and shrubs, but the sexual part of the cycle is only completed on Prunus persica and close relatives. Gynoparae produce oviparae (mating females) that feed and develop on peach leaves. Plant nutrition is a factor in the induction of winged forms, along with temperature, but there is also a strong genetic component. M. persicae is relatively cold resistant. Howling et al. (1994) described mortality of aphids at various cold temperatures and their results suggested that an acclimatized overwintering population of $M$. persicae would persist without significant mortality after a period of $7-10$ days with $-5^{\circ} \mathrm{C}$ frosts each night. It is highly variable species; strains, races and biotypes have been distinguished by morphology, colour, biology, host-plant preference, ability to transmit viruses and insecticide resistance (Field et al., 1994). M. persicae has been shown to transmit well over 100 plant virus diseases, in about 30 different families, including many major crops. Direct feeding damage can result in stunting and reduced root weight, but populations on most crops do not reach levels causing obvious symptoms such as chlorosis or leaf curling, and the production of copious honeydew with associated sooty mould and direct damage on potatoes (Sexson et al., 2005). M. persicae is a major pest everywhere potatoes are grown. It is the most important vector of Potato leaf roll virus (PLRV). Yield losses in sugar beet due to beet yellows are more serious if infection occurs early in the season and can be up to $30-50 \%$, with an increase also in the impurities present in 
the harvested sugar. On peach the aphid causes twisting of the young leaves and on nectarines, pitting on and discoloration of the young fruits (Barbagallo et al., 2007).

\section{Corn root aphid (Anuraphis maidi radicis)}

The corn root aphid is a serious pest dependent on the cornfield ant. During the winter, the ants store aphid eggs in their nests and in the spring carry the newly hatched aphids to weed roots, transferring them to corn roots when possible. The aphid stunts the growth of corn and causes plants to turn yellow and wilt. Corn root aphids also infest other grasses. The eastern spruce gall adelgid (Adelges abietis) produces pineapple-shaped galls 1 to $2.5 \mathrm{~cm}$ (0.4 to 1 inch) long composed of many cells, each containing about 12 aphid nymphs. The galls open in midsummer, releasing mature aphids that infect the same or another spruce. Infested branches often die, but individual trees vary in susceptibility. It appears as patches of yellow on the plant and may wipe out an entire field. Pale green adults have a dark green stripe down the back. Each female produces between 50 and 60 young per generation, and there are about 20 generations annually. It is controlled by parasites and insecticides and common in Uttarakhand.

\section{Pea aphid}

The pea aphid (Acyrthosiphon pisum) has two colour morphs, pale green and pinkish red. It overwinters on clover and alfalfa, migrating to peas in spring. The yellow bean mosaic virus it transmits is often responsible for killing pea plants. Each female produces 50 to 100 young in each of 7 to 20 generations a year. It is controlled by insecticides and weather conditions. It is also susceptible to natural predators such as ladybugs and to parasites such as the acrid Allothrombium pulvinum. The pea aphid's colour, which is determined by variations in genes that produce carotinoid pigments, may help it evade predators and parasites. Its ability to produce carotenoids is the result of a process known as horizontal gene transfer, in which the pea aphid acquired carotenoid genes from fungi tens of millions of years ago. Carotenoid production has been linked to energy (ATP; adenosine triphosphate) production in pea aphids. The development and mortality of juveniles and the life-span, age-specific fecundity and survivorship of adult aphids were recorded and used to construct life tables. The juvenile development period (from birth to adulthood) was longest at $11.9^{\circ} \mathrm{C}(16.8$ days on $\mathrm{cv}$. Scout and 16.2 days on $\mathrm{cv}$. Sancho) and shortest at $26.7^{\circ} \mathrm{C}$ ( 8.5 days on cv. Scout and 8.8 days on cv. Sancho). On both pea varieties juvenile mortality was highest at temperatures above $19.6^{\circ} \mathrm{C}$ and lowest at $19.6^{\circ} \mathrm{C}$. Highest cumulative juvenile mortality was recorded on cv. Scout at $26.7^{\circ} \mathrm{C}$ when only $9 \%$ of aphids survived from birth to reproductively mature adults. Fecundity rates were unaffected by temperature in the range tested on cv. Sancho but increased with increasing temperatures between 11.9 and $19.6^{\circ} \mathrm{C}$ on cv. Scout. These differences in life history parameters were reflected in the population growth $(\mathrm{rm})$ of aphids on both pea cultivars which increased with increasing temperatures between 11.9 and $23.1^{\circ} \mathrm{C}$ on cv. Sancho and 11.9 and $19.6^{\circ} \mathrm{C}$ on $\mathrm{cv}$. Scout, declining thereafter. Population growth was consistently greater at all temperatures for aphids reared on Sancho than those reared on Scout.

The potato aphid (Macrosiphum euphorbiae) begins as black eggs on rose plants, which hatch into pink 
and green young that feed on rosebuds and leaves. In early spring they migrate to potatoes, which are the summer host. One generation occurs every two to three weeks. It is the carrier of tomato and potato mosaic virus diseases that kill vines and blossoms. Many aphid species are monophagous. About $10 \%$ of species feed on different plants at different times of year. A new host plant is chosen by a winged adult by using visual cues, followed by olfaction using the antennae; if the plant smells right, the next action is probing the surface upon landing. The stylus is inserted and saliva secreted, the sap is sampled, the xylem may be tasted and finally the phloem is tested. Aphid saliva may inhibit phloem-sealing mechanisms and has pectinase that ease penetration. Data showed aphids consume more xylem sap than expected and they notably do so when they are not dehydrated and when their fecundity decreases. Plant sap is an unbalanced diet for aphids, as it lacks essential amino acids, which aphids, like all animals, cannot synthesise, and possesses a high osmotic pressure due to its high sucrose concentration. Essential amino acids are provided to aphids by bacterial endosymbionts, harboured in special cells, bacteriocyte. Potato aphid is common in potato cultivating zone of Uttarakhand.

\section{Rose aphid}

The Rose aphid (Macrosiphum rosae) is large and green with black appendages and pink markings. It is common on its only host, the cultivated rose. Natural predators are ladybird larva and aphid lions (lacewing larvae). Adult Macrosiphum rosae apterae are green or deep pink to red-brown. The antennae and sometimes the head are dark, as are the ends of the tibiae and femora. The abdomen may or may not have small marginal sclerites and antesiphuncular sclerites. The siphunculi are black and bent outwards and are reticulated on the apical $10-17 \%$. They are about $0.27-0.41$ times the body length and 1.9-2.4 times the length of the cauda. The cauda is pale yellow. The adult aptera of Macrosiphum rosae is 1.7-3.6 mm long. Macrosiphum rosae alatae have conspicuous black sclerites along the sides of the abdomen (see third picture above). They also have green and red colour forms. The rose aphid usually overwinters in the egg stage on rose bushes (its primary host), although in mild winters some adults may continue to reproduce parthenogenetically. In spring they colonise the young growth of rose, and produce large numbers of alates. These mostly migrate to their secondary hosts, teasels (Dipsaceae) and valerians (Valerianaceae). However, colonies can be found all summer on rose and the species is an important horticultural pest. Macrosiphum rosae has a worldwide distribution and common in Uttarakhand.

\section{Rosy apple aphid}

The rosy apple aphid (Dysaphis plantaginea) deforms fruit, producing "aphis apples." Its feeding activity causes leaves to curl about it, providing some protection from insecticide sprays. The life cycle involves plantain plants as alternate hosts from which the aphid returns to the apple tree to deposit eggs in the fall. It also attacks pear, hawthorn, and mountain ash. It is often controlled by natural enemies, chiefly syrphid flies, lady beetles, lacewings, and parasitic wasps and by insecticides. The woolly apple aphid (Eriosoma lanigerum) lives on roots and may stunt or kill apple trees. Aphids have antennae with two 
short, broad basal segments and up to four slender terminal segments. They have a pair of compound eyes, with an ocular tubercle behind and above each eye, made up of three lenses (triommatidia). They feed on sap using sucking mouthparts called stylets, enclosed in a sheath called a rostrum, which is formed from modifications of the mandible and maxilla of the insect mouthparts. Most aphids have a pair of cornicles (siphunculi), abdominal tubes on the dorsal surface of their fifth abdominal segment, through which they exude droplets of a quick-hardening defensive fluid containing triacylglycerols, called cornicle wax and defensive compounds can also be produced by some species.

\section{Mustard aphid (Lipapis erysemi)}

Mustard aphids are small, soft-bodied, pearl-shaped insects that have a pair of cornicles (honey tubes) projecting out from the fifth or sixth abdominal segment. There are four nymphal stages (instars). Wingless, female, aphids are yellowish green, grey green or olive green with a white waxy bloom covering the body. The winged, female, adult aphids have a dusky green abdomen with dark lateral stripes separating the body segments and dusky wing veins. Male aphids are olive-green to brown in colour. Both nymph and adults suck the sap from leaves, inflorescence or the developing pods. As aphids become more numerous, leaves become puckered, and curled. Curling may occur for infested leaves and at advanced stage plants may wither and die. The aphid attacks generally in December and continues till March. The most favourable temperature is $20^{\circ} \mathrm{C}$. Cloudy and cold weather help in accelerating the growth of insects. Plants are infested at all the stages and is common in Uttarakhand and Uttar Pradesh.

\section{Aphis craccivora}

Aphis craccivora is a cosmopolitan polyphagous crop pest of legumes. Though there have been reports of sexual morphs, Aphis craccivora aphids are thought to be primarily anholocyclic, i.e., only reproducing parthenogenetically, in northern latitudes, dying off during the winter and recolonizing temperate areas via migration each season. The aptera of Aphis craccivora is dark brown with (usually) a very solid black shiny carapace from the metanotum to abdominal tergite Aphis craccivora populations have a reduced sclerotic shield. The longest hair on the third antennal segment is usually $0.5-0.6$ times the basal diameter of that segment. Their siphunculi very rarely have any trace of constriction before the flange, and are 1.2 - 2.2 times the length of the cauda. The cauda has the distal part tapering and is 0.09 - 0.13 times body length. The body length is $1.16-2.3 \mathrm{~mm}$.

\section{Aphis spiraecola}

Aphis spiraecola is a relatively small aphid. Alatae are 1.2-2.2 $\mathrm{mm}$ and apterae 1.2-2.2 $\mathrm{mm}$, with largest body sizes. Its body colour is bright greenish-yellow or yellowish-green to apple-green. It has a brown head, mainly pale legs and antennae, but siphunculi and cauda that are dark-brown to black. Alatae have a dark-brown head and thorax, and a yellowish-green abdomen with dusky lateral patches on each segment. A. spiraecola has a diploid chromosome $(2 n=8)$. The species now has a worldwide distribution in temperate and tropical region (Swirski et al., 1991; Blackman and Eastop, 2000). 
It is a moderately polyphagous species. Primary (winter) hosts are Spiraea spp. and Citrus spp. It has numerous secondary host plants, in well over 20 families, particularly in the Caprifoliaceae, Compositae, Rosaceae, Rubiaceae and Rutaceae. The aphid has a preference for woody plants of a shrubby growth habit. Citrus and apple are the most important crop hosts (Blackman and Eastop, 2000), although grapefruit is almost immune to attack (Bannerman and Roitber, 2014). The first small colonies on new citrus growth occur by early February. In hot weather, nymphs can grow into adults within 5-6 days, leading to rapid population growth. On average, one aphid deposits 30 nymphs. Up to 14 generations may be produced in one year. An increased proportion of winged forms are produced in response to both over-crowding and a deteriorating food supply. These alates migrate in search of fresh young hosts. In the autumn, fruit formation enriches the sap in favour of the aphid and populations start to build up again. In winter, in temperate areas, few adults survive. Sexual females (oviparous) in holocyclic populations of $A$. spiraecola release a sex pheromone and display typical leg-waving behaviour during its release. In laboratory-reared aphids, the pheromone composition was $(+)$ $(4 \mathrm{aS}, 7 \mathrm{~S}, 7 \mathrm{aR})$ - nepetalactone and (-) -(1R,4aS,7S,7aR) - nepetalactol in the ratio of 6:1 to 8:1 (Hohn et al., 2003). Aphis spiraecola is mainly spread via the flight of winged forms. Aphids can also be carried on fruits and ornamental plants to new areas, where they may establish on host crops. Lacewing predators may be attracted to the aphid sex pheromone (Boo and Park, 2005).

\section{Cabbage aphid (Brevicoryne brassicae)}

The cabbage aphid (Brevicoryne brassicae) is small and gray-green with a powdery, waxy covering. It is found in clusters on the underside of leaves of cabbage, cauliflower, Brussels sprouts, and radishes. It overwinters as black eggs in northern regions but has no sexual stage in southern regions. When necessary, it can be controlled with the use of insecticides. The cooley spruce gall adelgid (Adelges cooleyi) causes formation of cone like galls about $7 \mathrm{~cm}$ ( 3 inches) long on the tips of spruce twigs. In midsummer when the galls open, adults migrate to Douglas firs to lay eggs. However, the life cycle may proceed on either spruce or Douglas fir. Control is by spraying with insecticide, removing galls before aphids emerge, and planting spruce and Douglas fir apart from each other. Monitoring of pest population and relative abundance of natural enemies is an important component of an area-wide pest control which overcome pesticide residue problem (Sarwar, 2009).

Cabbage is an excellent source of vitamin $\mathrm{K}$, vitamin C, and vitamin B6. It is also a very good source of manganese, dietary fibre, potassium, vitamin B1, foliate and copper (Dias, 2012). A number of limiting factors have been attributed for low productivity of cabbage, among them, the chief constraint in the production of cabbage is damage caused by pest complex right from germination till harvesting stage listed 51 insect pests to damage cruciferous crops throughout the world. In India, a total of 37 insect pests have been reported to feed on cabbage. Among the insect pests, aphids alone cause 9 - 96 per cent reduction in yield (Singh and Sharma, 2012). These aphids are widely distributed throughout the world on all Brassica crops. Plant produced many volatile compounds which guide them towards their host. Owing to the high fecundity and short generation period, it can reach population densities much higher than the economic threshold levels of 50-60 aphids/10 $\mathrm{cm}$ top central twig of plant making them 
intractable to control. Continuous application of similar pesticides may increase pest resistance and out beak of secondary pests or resurgence (Kumar and Paul, 2017).

\section{Black bean aphid (Aphis Fabae)}

Aphis fabae is also called bean aphid. Adults of Aphis fabae can weigh from as little as $200 \mu \mathrm{g}$ to as much as $1800 \mu \mathrm{g}$ a remarkable range in size for a single species. An extensive range in size also occurs among the adults in other species of aphid. Small individuals result when aphids develop either under crowded conditions or on a mature host-plant; large aphids result when the nymphs are reared in isolation or on young or senescent host-plants. A small adult produces fewer nymphs and also smaller nymphs than average. When aphids are overcrowded or feed on host-plants of poor quality, many aphids reach maturity that might otherwise fail to mature because of the ability of the species to produce viable adults of a great variety of size, including very small adults. Global average surface temperature is predicted to increase by 1.5 to $4.5^{\circ} \mathrm{C}$ by the end of the 21 st century. Due to this increase, major variability in climatic conditions could occur which includes more frequent droughts and higher mid-summer temperatures (IPCC, 2013). These predicted climate changes are likely to affect species distributions, life-history traits, trophic interactions and ecosystem functions (Traill et al., 2010).

\section{Control of aphid species}

Aphids are important sentinels of climate change. Insect metabolism and physiology display a high degree of sensitivity to air temperature, humidity, photoperiodism with daily and seasonal cycles, small plant feeding insects are regularly exposed to high ambient temperature stress (Neven, 2000). Temperature most directly affects insects by altering behavior and metabolic rate and downstream cellular and physiological processes (Bale et al., 2009). Aphids have complex life involve many morphological distinct forms and parthenogenetic generation alternating with asexual generation, and in about $10 \%$ of species this is associated with host alternation (Foottit et al., 2008). Aphid pests occurs throughout the temperate region of the world, causes direct damage by sucking plants sap which affects growth and yield of the crops (Gulidov and Poehling, 2013). Many species of aphids are pests in agriculture, forestry and horticulture. Abiotic factors including temperature, relative humidity, rainfall and total sunshine greatly influence the population of insect pests (Sanchis et al., 2005). Numerous factors influence the physiology of water-deficit stressed plants and subsequently the performance of insect herbivores. Depending on plant species, cultivar and age, duration and severity of water-deficit stress and aphid species, aphid abundance may be affected positively negatively or remain unaffected (Rivelli et al., 2013). Water stress or enhanced, had an adverse effect or had no effect on aphid population growth, depending on the cultivar and watering regime. No difference was recorded in the population dynamics of $M$. euphorbiae feeding on Beef master tomato plants subjected to different levels of water stress. In the case of the cultivar Scintilla, live aphids were less abundant on stressed plants than on well watered ones. The initial peak in aphid numbers was higher on the water stressed plants 
than on the control and then decreased to lower numbers than on the control. There were no differences in the numbers of aphids infesting stressed and control plants and fewer aphids on stressed than on control plants (Showler et al., 2013).

The severe effects of UV-B radiation along with photosensitizer on larval development, mortality and offspring were studied (Kumar et al., 2019). Studies with adult have shown that UV-B radiation act as immuno suppressive agent to aphids. A significant increase in the incidence of UV radiation as an apparent consequence of a decrease in the ozone layer has been reported in Patagonia (Villafane et al., 2001). With daily and seasonal cycles, small plant feeding insects are regularly exposed to high ambient temperature stress. Temperature most directly affects insects by altering behavior and metabolic rate and downstream cellular and physiological processes (Bale et al., 2007). Exposure to solar UV radiation affect productivity, reproduction, development, increase the mutation rate in phytoplankton, macro algae, have drastic biological impacts, including detrimental effects on individual organisms as well as on ecosystems (Jokinen et al., 2005). Various facultative symbionts can also associate with the pea aphid, some being known to benefit host aphids under high temperature conditions, aphids and their symbionts are interesting models for studying the effects of temperature and UV stress farmers are not with the ill effects of chemical pesticides and still using most of the systematic and organic insecticides to control this insect pest (Ali and Rizvi, 2007). In laboratory experiments, low temperature promoted, while high temperature tended to suppress, the development of winged forms Temperature is both a selective pressure and a modulator of the diapause expression in insects from temperate regions. Thus, with climate warming, an alteration of the response to seasonal changes is expected, either through genetic adaptations to novel climatic conditions or phenotypic plasticity (Tougeron et al., 2017).

\section{Conclusion}

Thus, from the above discussion it was evidenced that aphid community play an important role in agricultural ecosystem in particular to Uttarakhand state of India. Now a days, the aphid communities are being affected by several natural and anthropogenic factors. However, aphid causes damage to the crops like mustard, cabbage, pea, potato, bean, lemon, cotton etc. and flowers like rose, lily, marigold etc. This chapter provided research oriented information about aphid diversity, ecology and inventory in the mountainous region.

\section{Acknowledgement}

Authors are thankful to Wadia Institute of Himalayan Geology, Dehradun and UGC New Delhi No. F 43-562/2014 (SR) for instrumental support. 


\section{References}

Akey, D.H. and Butler, J.G.D. (1989). Developmental rates and fecundity of apterous Aphis gossypii on seedlings of Gossypium hirsutum. Southwestern Entomologist, 14(3): 295-299.

Ali, A. and Rizvi, P. Q. (2007). Development and predatory performance of Coccinella septempuncata L. (Coleoptera: Coccinellidae) on different aphid species. International Journal of Biological Science, 7: 1478.

Bale, J.S., Masters, G.J., Hodkinson, I.D., Awmack, C., Benzemer, T.M., Brown, V.K., Butterfield, J., Buse, A., Harrington, R., Hartley, S., Jones T.H., Lindroth, R.L., Watt, A.D. and Whittaker, J.B. (2009). Herbivory in global climate change research: Direct effects of rising temperature on insect herbivores. Global Change Biology, 8: 1.

Bale, J.S., Ponder, K.L. and Pritchard, J. (2007). Coping with Stress in Aphids as Crop Pests. Eds. Van Emden, H. F. and Harrington, pp. 287-303 (CAB International).

Bannerman, J.A. and Roitberg, B.D. (2014). Impact of extreme and fluctuating temperatures on aphid-parasitoid dynamics. Oikos, 123(1): 89-98.

Barbagallo, S., Cocuzza, G., Cravedi, P. and Komazaki, S. (2007). 29 IPM Case Studies: Deciduous Fruit Trees. Aphids as crop pests, pp. 651.

Barlow, C.A., (2007). Development, survival, and fecundity of the potato aphid, Macrosiphum euphorbiae, at constant temperatures. The Canadian Entomologist, 94: 667-671.

Belshaw, R. and Quicke, D.L.J. (2001). A molecular phylogeny of the Aphidiinae (Hymenoptera: Braconidae). Molecular Phylogenetics and Evolution, 7: 281-293.

Bethke, J.A. and Paine T.D. (1991). Screen hole size and barriers for exclusion of insect pests of glasshouse crops. Journal of Entomological Science, 26(1): 169-177.

Bhatnagar, A., Somani, A.K. and Chander, S. (2012). Buildup of Myzus persicae and development of mosaic on potato in central India. Potato Journal, 39(2): 208-210

Blackman, R.L. and Eastop, V.F. (1984). Aphids on the World's Crops. An Identification and Information Guide. Chichester UK John Wiley.

Blackman, R.L. and Eastop, V.F. (2000). Aphids on the World's Crops: An Identification and Information Guide. Ed. 2, Chichester UK John Wiley. pp. 466.

Blua, M.J. and Perring, T.M. (1992). Alatae production and population increase of aphid vectors on virus-infected host plants. Oecologia, 92(1): 65-70.

Boo, K.S. and Park, K.C. (2005). Insect semiochemical research in Korea: overview and prospects. Applied Entomology and Zoology, 40(1): 13-29.

Chan, C.K. and Forbes, A.R. (2019). Life cycle of a spiral gall aphid, Pemphigus spirothcae (Homoptera: Aphididae), on Poplar in British Columbia. Journal of the Entomological Society of British Columbia, 72: 26-30.

Chandla, V.K., Khurana, S.M.P. and Garg, I.D. (2004) Aphids, their importance, monitoring and management in seed potato crop. Technology Bulletin, 61: 12.

Chen, C.Y., Chiu, M.C. and Kuo, M.H. (2013). Effect of warming with temperature oscillations on a low latitude aphid, Aphis craccivora. Bulletin of Entomological Research, 103(4): 406-413.

Chen, Y., Olson, D.M. and Ruberson, J.R. (2010). Efects of nitrogen fertilization on tritrophic interactions. Arthropod-Plant Interact, 4: 81-94.

Dale, A.G. and Frank, S.D. (2017). Warming and drought combine to increase pest insect fitness on urban trees. Plos One, 12 (3): $1-14$

Davis, J.A., Radcliffe, E.B. and Ragsdale, D.W. (2006). Effects of high and fluctuating temperatures on Myzus persicae (Aphididae). Environmental Entomology, 35: 1461-1468.

De Barro, P.J. and Carver, M. (1997). Cabbage whitefly, Aleyrodes proletella (L.) (Hemiptera: Aleyrodidae), newly discovered in Australia. Australian Journal of Entomology, 36: 255.

Dey, D. and Akhtar, M.S. (2007). Diversity of natural enemies of aphids belonging to Aphidiinae (Hymenoptera: Braconidae) 
in India. Journal of Asia-Pacific Entomology, 10(4): 281-296.

Dey, S.R. (2016). Seasonal occurrence and altitudinal distribution of Neuroptera (Insecta) in Uttarakhand, India. The Beats of Natural Science, 2(4): 1-13.

Dias, J. S. (2012). Nutritional Quality and Health Benefits of Vegetables: A Review. Food and Nutrition Sciences, 3: $1354-1374$.

Ekukole, G. (1990). Effects of some selected plants on the fecundity of Aphis gossypii Glover under laboratory conditions. Coton Fibres Tropicales, 45(3): 263 - 266.

Field, L.M., Javed, N., Stribley, M.F. and Devonshire, A.L. (1994). The peach-potato aphid Myzus persicae and the tobacco aphid Myzus nicotianae have the same esterase-based mechanisms of insecticide resistance. Insect Molecular Biology, 3(3): 143-148.

Foottit, R.G., Maw, H.E.L., VonDohlen, C.D. and Hebert, P.D.N. (2008). Species identification of aphids (Insecta: Hemiptera: Aphididae) through DNA barcodes. Molecular Ecology Resources, 8: 1189.

Ghosh, L.K. and Verma, K.D. (1990). Discovery of sexual female of Myzus persicae (Sulzer) (Homoptera: Aphididae) with redescription of its alate male in India. Journal of Aphidology, 4(1-2),: 30 - 35.

Grantham, M., Jennifer, A.B., Tagu, D. and Trionnaire, G. (2015). Integrative genomic approaches studying epigenetic mechanismsof phenotypic plasticity in the aphids. Insects Genomics. 1: 95 -117.

Guldemond, J.A., Tigges, W.T. and De Vrijer, P.W. (1994). Host races of Aphis gossypii (Homoptera: Aphididae) on cucumber and chrysanthemum. Environmental Entomology, 23(5): 1235 - 1240.

Gulidov, S. and Poehling, H.M. (2013). Control of aphids and whiteflies on Brussels sprouts by means of UV absorbing plastic films. Journal of Plant Diseases and Protection, 120(3): 122-130.

Han, P., Wang, Z.J., Lavoir, A.V., Michel, T., Seassau, A., Zheng, W.Y., Niu, C.Y. and Desneux, N. (2016). Increased water salinity applied to tomato plants accelerates the development of the leaf miner Tuta absoluta through bottom-up effects. Scientific Reports, 6(1): 1-12.

Hance, T., van Baaren, J., Vernon, P. and Boivin, G. (2007). Impact of extreme temperatures on parasitoids in a climate change perspective. Annual Review of Entomology, 52: 107-126.

Harrington, R. and Maurice H. (2010). Seasonal biology of Aphids in the face of global changes. Ecology, 333(6): 497-503.

Harrington, R., Bale, J.S. and Tatchell, G.M. (1995). Aphids in a changing climate, in: R. Harrington, Insects in a Changing Environment, Academic Press, London, pp. 125-155.

Höhn, H., Höpli, H., Graf, B., Meier, J. and Kull, H. (2003). The green citrus aphid-also a problem in Swiss arboriculture. Obstund Weinbau, 139(11): 9-11.

Howling, G.G., Bale, J.S. and Harrington, R. (1994). Effects of extended and repeated exposures to low temperature on mortality of the peach potato aphid Myzus persicae. Ecological Entomology, 19(4): 361-366.

Huberty, A.F. and Denno, R.F. (2004). Plant water stress and its consequences for herbivorous insects: A new synthesis. Ecology, 85: 1383-1398.

Hullé, M., Robert, Y. and Gamon, A. (2010). Developing the AGRAPHID database, the permanent suction trap network for monitoring alate aphids. Comptes Rendus de l'Académie d'Agriculture de France, 73(7): 59-70.

IPCC. Climate change (2013). The physical science basis. Working group I contribution to the fifth assessment report of the Intergovernmental Panel on Climate Change. Cambridge University Press, pp. 1-1535.

Irwin, M.E., Kampmeier, G.E. and Weisser, W.W. (2007). Aphid movement: pros and consequences, in: H.F. van Emden, R. Harrington (Eds.), Aphids as Crop Pests, CABI, UK, pp. 153 - 186.

James, C.K., Keith, G. and Perry, L. (2004). Transmission of plant viruses by aphid vectors. Molecular Plant Pathology, 5(5): 120.

Jefs, C.T. and Leather, S.R., (2014). Efects of extreme, fuctuating temperature events on life history traits of the grain aphid. Sitobion avenae. Entomology: Experimental Applied, 150: 240 - 249.

Jokinen, E. I., Makkula, S. E., Salo, H. M. and Immonen, A. K. (2005). Effects of Short and long term ultraviolet-B irradiation on the immune system of common Carp (Cyprinus carpio). Photochemistry and Photobiology, 81: 595.

Kültz, D. (2005). Molecular and evolutionary basis of the cellular stress response. Annual Review of Physiology, 67: 225-257.

Kumar S., Malik D.S. and Rathi P. (2019). Effect of UV-B radiation on mortality and enzymes level in fish larva of Tor tor and Schizothorax richardsonii on laboratory scale. Journal of Applied and Natural Science. 11(2): 462-467. 
Kumar, J. (2016). Infochemicals: An effective and environment friendly management of insect pests for sustainable agriculture. International Journal of Agricultural Invention, 1: 218-224.

Kumar, J. and Paul, B. (2017). Population dynamics of aphid, Myzus persicae (Sulzer) (Hemiptera: Aphididae) on different Brassica species. Agricultural Science Digest, 37: 64-67.

Liu, J.P., Zhang, X.Q. and Zhang, Q. (2005). Study on methods for controlling aphids in commercial lucerne production. Pratacultural Science, 22(10): 74-77.

Martin J.H. (2008). The identification of common aphid pests of tropical agriculture. Tropical Pest Management, $29: 395-411$.

Neven, L.G. (2000). Physiological response of insects of heat. Elsevier Post Harvest Biology and Technology, 21: 103.

Nguyen, T.T.A., Michaud, D. and Cloutier, C. (2009). A proteomic analysis of the aphid Macrosiphum euphorbiae under heat and radiation stress. Insect Biochemistry and Molecular Biology, 39: 20-30.

Nozato, K. (1990). Behavioral traits of Aphis gossypii Glover alatae (Homoptera: Aphididae), in relation to its flight and reproduction. Japanese Journal of Applied Entomology and Zoology, 34(2): 121-126.

Owusu, E.O., Brempong-Yeboah, C.Y., Horiike, M. and Hirano, C. (1994). Some biochemical changes in garden egg (Solanum integrifolium) Legon" 18" due to feeding by Aphis gossypii (Homoptera: Aphididae). Phyton (Buenos Aires), $55(1)$ : 147 152.

Pritchard, J. and Vickers, L.H. (2017). Aphids and stress in Aphids as Crop Pests. (Eds. Van Emden, H. F. and Harrington, R.), (CABI 2017), pp. 132-147.

Rivelli, A.R., Trotta, V., Toma, I., Fanti, P. and Battaglia, D. (2013). Relation between plant water status and Macrosiphum euphorbiae (Hemiptera: Aphididae) population dynamics on three cultivars of tomato. European Journal of Entomology, 110: $617-625$.

Sabri, A., Vandermoten, S., Leroy, P.D., Haubruge, E., Hance, T., Thonart, P., De Pauw, E. and Francis, F. (2013). Proteomic investigation of aphid honeydew reveals an unexpected diversity of proteins. Plos One, 8(9): 62-71.

Sanchis, A.A., Latorre, F., Gonza lez-Candelas, and Michelena, J.M. (2005). An 18 S rDNA-Based Molecular Phylogeny of Aphidiinae (Hymenoptera: Braconidae). Molecular Phylogenetics and Evolution, 2: 180 - 194.

Sarwar, M. (2009). Populations synchronization of aphids (Homoptera: Aphididae) and ladybird beetles (Coleoptera: Coccinellidae) and exploitation of food attractants for predator. Biological Diversity Conservation, 2: 85 - 89.

Sexson, D.L., Wyman, J., Radcliffe, E.B., Hoy, C.J., Ragsdale, D.W. and Dively, G.P. (2005). Potato. Vegetable Insect Management, R. Foster and B. Flood, eds., Meister Publishing, Willoughby, OH, USA, pp. 92-107.

Sharma, D. and Rao, D.V. (2012). A field study of pest of cauliflower cabbage and okra in some areas of Jaipur. International Journal of Life Sciences Biotechnology and Pharma Research, 2: 1 - 6.

Shik, J.Z., Kay, A.D. and Silverman, J. (2014). Aphid honeydew provides a nutritionally balanced resource for incipient Argentine ant mutualists. Animal Behaviour, 95: 33 - 39.

Showler, A.T. (2013). Water deficit stress-host plant nutrient accumulations and associations with phytophagous arthropods. Abiotic stress-plant responses and applications in agriculture, pp. 387-410.

Singh, G., Singh, N.P. and Singh, R. (2014). Food plants of a major agricultural pest Aphis gossypii glover (Homoptera: Aphididae) from India: An updated checklist. International Journal of Life Sciences Biotechnology and Pharma Research, 3(2): 1.

Singh, R. and Srivastava, P.N. (1989). Life table studies of an aphid hyper parasitoid Alloxysta pleuralis (Cameron) (Hym., Alloxystidae). Journal of Applied Entomology, 107(15): 351-356.

Singh, Y.P. and Sharma, K.C. (2012). Integrated approach to manage the mustard aphid, Lipaphis erysimi (Kalt) (Homoptera: Aphididae) in oil seed Brassica crops-A review. Journal of Aphidology, 16: 77-88.

Smith, P.T., Kambhampati, S., Voelkl, W. and Mackauer, M. (1999). A phylogeny of aphid parasitoids (Hymenoptera: Braconidae: Aphidiinae) inferred from mitochondrial NADH 1 dehydrogenase gene sequence. Molecular Phylogenetics and Evolution, 11: 236 - 245.

Strogani, H.L.G. (1984). Handbooks for Identification of British Insects. 2(6): 75-124.

Swirski, E., Izhar, Y. and Wysoki, M. (1991). Appearance of Aphis gossypii Glover and Aphis spiraecola Patch (Rhynchota: Aphidoidea) on avocado, persimmon and macadamia. Alon Hanotea, 45(5): 1-10.

Tougeron, K., Le Lann, C., Brodeur, J. and Van Baaren, J. (2017). Are aphid parasitoids from mild winter climates losing their 
winter diapause? Oecologia, 183(3): 619 - 629.

Traill, L. W., Lim, M.L.M., Sodhi, N.S. and Bradshaw, C.J.A. (2010). Mechanisms driving change: altered species interactions and ecosystem function through global warming. Journal of Animal Ecology, 79: 937-947.

Van Baaren, J., Le Lann, C. and van Alphen, J.J. (2010). Consequences of climate change for aphid-based multi-trophic systems. In Aphid Biodiversity under Environmental Change. Springer, Dordrecht, pp. 55 - 68

Villafane, V.E., Buma, A.G.J., Helbling E.W. and De Boer, M.K. (2001). Patterns of DNA damage and photo inhibition in temperate south- Atlantic Pico phytoplankton exposed to solar ultraviolet radiation. Journal of Photochemistry and Photobiology, 62: 9 .

Yamamura, K. and Kiritani, K. (1998). A simple method to estimate the potential increase in the number of generations under global warming in temperate zones. Applied Entomology and Zoology, 33: 289 - 298.

Zepeda P.F., Villegas C. and Lavandero B. (2017). Host genotype endosymbiont association and their relationship with aphid parasitism at the field level. Ecological Entomology, 42(95): 65.

Zhang, G.X. and Zhong, T.S. (1990). Experimental studies on some aphid life-cycle patterns and the hybridization of two sibling species. In: Campbel RK, Eikenbary RD, Eds. Aphid-Plant genotype interactions. New York, USA: Elsevier Press.

Zhaozhi, L., Likai, F., Guizhen, G., Ling-Ling, G., Han, P., Sharma, S. and Zalucki, M.P. (2017). Differences in the hightemperature tolerance of Aphis craccivora (Hemiptera: Aphididae) on cotton and soybean: implications for ecological niche switching among hosts. Applied Entomology and Zoology, 52(1): 9 - 18.

$* * * * *$

Cite this chapter as: Kumar, S., and Saini, D. (2021). Ecology and diversity of plant aphids in Garhwal region of Uttarakhand, India. In: Biological Diversity: Current Status and Conservation Policies, Volume 1, Eds. Kumar., V., Kumar, S., Kamboj, N., Payum, T., Kumar, P. and Kumari, S. pp. 256-274, https://doi.org/10.26832/aesa2021-bdcp-017 